\title{
Decadal changes in vegetation of a subarctic salt marsh used by lesser snow and Canada geese
}

Post-print/Accepted manuscript

P.M. Kotanen

K.F. Abraham

Kotanen, P.M. \& Abraham, K.F. Plant Ecol (2013) 214: 409. doi:10.1007/s11258-013-0178-x

The final publication is available at Springer via http://dx.doi.org/10.1007/s11258-013-0178-x

\section{HOW TO CITE TSPACE ITEMS}

Always cite the published version, so the author(s) will receive recognition through services that track citation counts, e.g. Scopus. If you need to cite the page number of the TSpace version (original manuscript or accepted manuscript) because you cannot access the published version, then cite the TSpace version in addition to the published version using the permanent URI (handle) found on the record page. 
1 Word count: 5999 (abstract, text, acknowledgements, and references)

4 Decadal changes in vegetation of a subarctic salt marsh used by

5 lesser snow and Canada geese

6 P.M. Kotanen ${ }^{* 1}$

7 Department of Ecology and Evolutionary Biology

8 University of Toronto Mississauga

93359 Mississauga Road N

10 Mississauga ON L5L 1C6, Canada

11 e-mail: peter.kotanen@utoronto.ca

12 telephone : 905-82805365; fax 905-828-3792

13

14 K.F. Abraham

15 Ontario Ministry of Natural Resources

16 Wildlife Research \& Development Section

172140 East Bank Drive

18 Peterborough, ON K9J 8M5, Canada

19 e-mail: ken.abraham@ontario.ca

$21 *$ Author for correspondence

\footnotetext{
${ }^{1}$ Author Contributions: PMK and KFA conceived and designed the study. PMK and KFA carried out the field work. PMK analyzed the data. PMK and KFA wrote the manuscript.
} 
23 Abstract: In the Hudson-James Bay system, grubbing and grazing by lesser snow geese have

24 resulted in severe devegetation of coastal marshes. These changes likely represent an example of

25 an alternative stable state; however, long-term datasets documenting whether revegetation is

26 occurring are scarce. Here, we report results of a 10-year study investigating changes in the state

27 of a degraded salt marsh system on the north coast of Akimiski Island, Nunavut. Four transects

28 were intensively sampled in 1998 and 2008, two within the dense nesting and brood-rearing area

29 of a snow geese colony, one on the colony edge, and one outside it; all of these sites were also

30 used by broods of Canada geese. Key forage species (Puccinellia phryganodes, Festuca rubra,

31 Carex subspathacea) were less common near the colony centre than elsewhere; biomass of

32 Puccinellia also tended to be lower in more central areas. Forage species often increased in

33 abundance between samplings, but the magnitude of changes was small. In contrast, non-forage

34 species (Salicornia, Spergularia, Glaux) often reached high abundance within the colony centre;

35 some (Salicornia) decreased while others (Spergularia) increased. We argue the degraded state

36 was initiated by foraging damage from an exceptional stopover of 295,000 staging birds in 1972

37 and that the combined foraging pressure of relatively small numbers of nesting and migrant

38 geese since then, coupled with soil changes, has been sufficient to maintain devegetated areas as

39 a persistent alternative state. Whether or not this state is truly stable, further recovery is likely to

40 be very slow.

41 Key words: alternative states; Festuca rubra; foraging; Hudson-James Bay; Puccinellia

42 phryganodes.

43 


\section{Introduction}

45 Vertebrate herbivores are important components of northern ecosystems and have

46 significant effects on the structure and functioning of plant communities, including species

47 composition, nutrient cycling, and other ecosystem characteristics (Jefferies et al. 1994). For

48 instance, consumption of forage plants (primarily grasses and sedges) by geese has important

49 impacts at many arctic and subarctic coastal wetland sites (e.g., lesser snow geese: Jefferies et al.

50 2003; black brant: Person et al. 2003; greater snow geese: Gauthier et al. 2004; pink-footed

51 geese: van der Wal et. al 2007). Grazing by moderate densities of geese can sustain or even

52 stimulate plant community productivity in a positive feedback through increased nutrient

53 cycling, resulting in a grazing lawn (Cargill and Jefferies 1984; Hik and Jefferies 1990; Hik et al.

54 1991; Jefferies et al. 2003). However, a second feedback involving grubbing for shoots and

55 rhizomes by dense aggregations of spring migrating or pre-nesting birds can have devastating

56 effects on northern plant communities, especially when coupled with intense summer grazing by

57 local resident birds (Jefferies 1988). For instance, at La Pérouse Bay, Manitoba, sporadic spring

58 staging events by northbound lesser snow goose (Chen caerulescens caerulscens) migrants

59 (Jefferies and Rockwell 2002) and a rapid increase in the size of the local nesting colony over

60 two decades led to extensive devegetation of intertidal grazing flats and loss of graminoid

61 vegetation from fresh-water supratidal areas (Jefferies et al. 2003; Abraham et al. 2005). Effects

62 of foraging by large numbers of lesser snow geese similar to those at La Pérouse Bay have now

63 been observed at multiple locations in the Hudson-James Bay system, including Southampton

64 Island, the Nunavut coast of Hudson Bay, Cape Henrietta Maria (Ontario) and Akimiski Island

65 in James Bay (Abraham and Jefferies 1997; Didiuk and Ferguson 2005; Alisauskas et al. 2006;

66 Jefferies et al. 2006; Abraham et al. 2012). 
68 Koppel et al. 1997; Beisner et al 2003; Suding et al. 2004). For example, the introduction of

69 cattle and European rabbits into Chile is believed to have stably converted sclerophyllous

70 matorral forest to savanna (Holmgren 2002), a change now very difficult to reverse even with

71 protection from grazing. The available evidence indicates that devegetation of northern wetlands

72 due to goose foraging also is very difficult to reverse. In intertidal and supratidal sites, changes to

73 soil including increased salinity and anoxia can severely restrict recolonization by plants other

74 than halophytes such as Salicornia (Srivastava and Jefferies 1995, 1996; Handa et al. 2002;

75 McLaren and Jefferies 2004). In freshwater sites, graminoids such as Carex and Eriophorum

76 apparently have difficulty recolonizing the moss carpets that develop in areas from which

77 vascular plant cover has been removed (Kerbes et al. 1990; Kotanen and Jefferies 1997).

78 Revegetation may be possible if foraging pressure is reduced (Handa et al. 2002); however, as

79 vegetation cover declines, pressure may be sustained or even increased in remaining patches of

80 forage plants.

81 Despite their importance for understanding the trajectories of dynamically slow northern

82 plant communities, multi-year datasets documenting vegetation change are rare for sites

83 seriously impacted by geese; La Pérouse Bay (Jefferies and Rockwell 2002; Jefferies et al. 2003)

84 provides the most extensive exception. As a result, evidence that foraging geese have created

85 alternative stable states usually has been inferred from descriptions of existing vegetation (e.g.,

86 Kerbes et al. 1990) or remote sensing (e.g., Jefferies et al. 2006), rather than being directly

87 demonstrated by repeated observations of affected communities. In this paper, we present the

88 first analysis of a dataset from Akimiski Island, Nunavut, a location about $1000 \mathrm{~km}$ away from

89 La Pérouse Bay. The north shore of this island has been severely affected by geese (Jefferies et

90 al. 2006). Much of the devegetation at this site may have resulted from a single event in 1972, 
91 when an estimated 295,000 birds were delayed at this site during their northward migration

92 (Curtis 1973). Since that event, these salt marshes have been exposed to continuous foraging by

93 lesser snow geese from a small breeding colony and breeding Canada geese of the Southern

94 James Bay Population (Branta canadensis interior). In 1998, we intensively sampled supratidal-

95 intertidal sites; in 2008, we re-sampled the same locations, providing a record of vegetation

96 change over the intervening decade. Our dataset allows us to determine whether substantial

97 recovery has occurred at these coastal sites, or whether sustained foraging pressure from the

98 relatively small local goose population, coupled with soil changes, has been sufficient to slow or

99 prevent revegetation.

100 Methods

101 Study Site

102 Akimiski Island, Nunavut Territory, Canada $\left(53^{\circ} \mathrm{N}, 81^{\circ} \mathrm{W}, 3800 \mathrm{~km}^{2}\right)$ is the largest island

103 in James Bay. During this study, lesser snow geese nested in a relatively dense, discrete colony

104 of about 4000 birds along a $35 \mathrm{~km}$ stretch of the north shore of this island (Abraham et al. 1999),

105 while nesting Canada geese occurred at lower densities throughout the island (Leafloor et al.

106 1996, 2000), including the areas used by snow geese (Fig. 1). These species intensively graze

107 leaves of forage plants in intertidal and supratidal areas during the breeding season, as well as in

108 the freshwater fens adjacent to the supratidal areas. Nesting and brood rearing snow geese as

109 well as nesting and brood-rearing Canada geese are responsible for most summer grazing close

110 to the snow goose colony, so this area is the most intensively used segment of the north shore.

111 Snow geese also extensively grub roots and shoots of forage plants in early spring as do Canada

112 geese, to a lesser extent. 
114 Puccinellia phryganodes, in the lower marsh, with the forage sedge Carex subspathacea in the

115 upper marsh in areas more influenced by fresh water, including streams that drain the interior of

116 the island, and seepage areas near supratidal zone (Martini and Glooschenko 1983). However,

117 intense grazing pressure in the area of the snow goose colony has depleted these species (Figs

118 2a-c), largely replacing them with unvegetated mudflats (O et al. 2005; Jefferies et al. 2006). The

119 forage grass Festuca rubra has also been reduced in extent, but still locally occurs in nearly pure

120 pastures in supratidal areas used by nesting and brood-rearing snow geese and Canada geese.

121 Patches of short, intensely grazed plants are interspersed with infrequently grazed taller plants

122 and exposed formerly-vegetated mudflats (Fig. 2b; O et al. 2006).

123 Sampling

124 Five permanent transects were established along the north shore of Akimiski Island in

1251998 at intervals of 6-10 km (Fig. 1). Those near the Thompson and Stitt rivers were located

126 within the dense nesting area and principal brood rearing area of the current snow goose nesting

127 colony; the Lumsden River transect was beyond the west edge of the dense nesting colony but

128 within the brood rearing area; the Ministik River transect was east of the colony and the brood-

129 rearing area (all place names unofficial). All of these areas were also used by pre-breeding snow

130 geese, by broods of Canada geese, spring migrant brant, and moult migrant Canada geese.

131 Transects extended from near the end of vegetation in the lower intertidal zone to the upper end of

132 the supratidal zone traversing the zones roughly perpendicular to the shoreline; they ranged in

133 length from approximately $850 \mathrm{~m}$ to $1550 \mathrm{~m}$, and were marked at both ends with angle iron posts

134 driven into the sediment.

135 These transects were sampled between 14-22 July 1998 and again between 19-22 July

136 2008, when annual growth and flowering of most species was well advanced. A measuring tape 
137 was laid along the transect and the presence or absence of all vascular plant species was noted at

$1381 \mathrm{~m}$ intervals (within a "quadrat" approximately $10 \mathrm{~cm}$ in diameter). Sites with no plant cover

139 included mudflats where plants may or may not previously have occurred, as well as sites

140 unsuitable for forage plant growth, such as ponds, unstable gravel bars, large rocks, and drainage

141 channels; it often was difficult to distinguish among these categories.

142 In 2008, transects were re-located using landmarks, GPS co-ordinates, and compass

143 bearings. The original seaward end stakes were found for the Stitt, Lumsden, and Ministik

144 transects; no end stake was found for the Thompson transect, but the transect passed close to an

145 observation tower that was used for alignment to the GPS end point. We do not assume exactly the

146 same points were sampled in both years; however, the 1998 and 2008 transects represent samples

147 of very closely proximate areas.

148 We also sampled above ground standing crop in one Puccinellia- and one Festuca-

149 dominated area at the Thompson, Stitt, and Ministik sites in 1998 and 2008. The Lumsden site

150 also was sampled in 1998, but not 2008; this site was last sampled in 2006. On each date, we

151 deliberately chose sampling locations with the best available vegetation, to describe the

152 maximum potential forage at that site. Three to five $100 \mathrm{~cm}^{2}$ turfs were collected in each

153 vegetation type and clipped, washed, and dried to constant weight in a drying oven. Biomass was

154 recorded to the nearest 0.01g. Sampling dates (23 July 1998, 26 July 2006, 26 July 2008)

155 corresponded to late brood rearing stage for geese and was near the peak of the growing season.

156 This technique sets an upper limit to potential forage availability in surviving grazed vegetation,

157 but should not be taken as an average value; a random quadrat in most of our study area would

158 contain little to no green biomass (see below). Thus, these values also should not be taken as a

159 measure of average change between samplings, but rather a comparison of best conditions at each

160 sampling. 
Data were analyzed with JMP 10 (2010, SAS Institute Inc., Cary, NC, USA). For each

163 transect, data were grouped by 100m sections, beginning at the most seaward point. As there

164 were obvious differences between transects, and because our principal goal was to describe

165 changes in each transect over time, we analyzed each transect separately. Data were analyzed

166 using generalized linear models with a binomial distribution and a logit link, and Firth bias-

167 adjusted estimates. We compared the number of occurrences of each species among different

168 segments of the same transect, and between the same segment at different sampling dates, using

169 a factorial design (position $\times$ year); we treated both year and position on the transect as fixed

170 factors. A significant "position" term means a species was not evenly distributed along a

171 transect; a significant "year" term indicates a species' overall abundance changed between years;

172 a significant interaction means that a species' position shifted between years. In some cases a full

173 analysis was not possible, usually because a species was very rare or absent in one year, leading

174 to inestimable parameters. In response, we dropped the interaction terms from such models to

175 separately test whether the overall frequency of a species differed between years and among

176 locations along a transect; such tests should be treated with caution since they ignore position $\times$

177 year interactions. Species with a total of fewer than 60 occurrences in either year gave unreliable

178 estimates and conservatively were excluded from analysis.

179 Biomass was analyzed in a 2-way standard least squares ANOVA (site $\times$ year) for the

180 Thompson, Stitt, and Ministik sites. The Lumsden site was excluded from this analysis, since

1812008 data were not available; however, we separately calculated mean and SEM values for this 182 site for 1998 and 2006. 


\section{Results}

184 Extent of sampling

We sampled a total of more than 6000 quadrats (6 km) along our transects in 1998, and more than 5400 in 2008. As we ended sampling of transects at slightly different lengths in each year, we discarded any positions not represented in both samplings to equalize transect length.

188 We then truncated each transect at the nearest $100 \mathrm{~m}$ point, so that all sections within each

189 transect were equally sized. As transects extended from the lower intertidal to the beginning of

190 freshwater vegetation, these deletions meant losing some information on freshwater areas, but

191 little from the intertidal or supratidal zones, which were the focus of this study. Our final sample 192 size was 5200 quadrats in both 1998 and 2008; our shortest transect (Stitt) was 700m long, while 193 our longest (Lumsden) was 1500m long (Fig. 1).

194 Overall patterns

195 In the intertidal zone, our most commonly occurring species were Puccinellia

196 phryganodes, Carex subspathacea, Spergularia spp., Salicornia cf. borealis, and Glaux

197 maritima; in the supratidal, we also frequently recorded Festuca rubra. Mosses were rare or

198 absent in the areas sampled. In addition to these common species, we infrequently encountered

199 several other grasses (e.g., Dupontia fisheri, Calamagrostis spp., Hierochlöe odorata), sedges

200 (Carex spp., Eleocharis spp.), herbaceous dicots (e.g., Senecio congestus, Honkenya peploides,

201 Hippuris spp.), and woody species (Shepherdia canadensis, Myrica gale). Most of these occurred

202 in freshwater areas, which our transects barely entered; therefore, we made the decision to restrict

203 analyses to the principal intertidal and supratidal species. See Blaney and Kotanen (2001) for a

204 complete species list for this site.

205 The primary intertidal forage species Puccinellia phryganodes and Carex subspathacea 206 (hereafter Puccinellia and Carex) were found at all transect sites, as was the primary supratidal 
207 forage species Festuca rubra (hereafter Festuca) (Figs 3,4). However, at both samplings there

208 was a tendency for these species to be less frequent at transects within the snow goose colony

209 than in surrounding areas (Fig. 4). For instance, Puccinellia was much more frequent at the

210 Ministik than at sites within the snow goose colony (Thompson, Stitt). Similarly, Carex was

211 much scarcer within the colony than to the east (Ministik), possibly reflecting a greater

212 freshwater input at this site; Carex also was more abundant west of the dense colony (Lumsden)

213 in 2008, though not in 1998. Festuca was more abundant west of the colony than inside it;

214 Festuca also was more abundant east of the colony than within it in 1998, though not in 2008. No

215 forage species reached peak abundance within the snow goose nesting area.

216 In contrast to forage species, non-forage species often reached high abundances inside the

217 snow goose colony, as well as outside it (Figs. 5,6). The highly halophytic Salicornia occurred

218 abundantly at the Lumsden River in 1998, but otherwise was scarce. Spergularia similarly was

219 restricted to the Lumsden transect in 1998, but had spread east by 2008, when it was abundant at

220 the Thompson, present at the Stitt, and frequent at the Ministik. Glaux was frequent at transects

221 both inside and outside the colony, but especially at the Thompson.

222 Changes in individual species

223 The overall frequency of all forage species tended to increase between 1998 and 2008

224 (Figs 3,4), though the absolute magnitude of these changes usually was small $(\leq 10 \%$ of quadrats

225 per transect, or 1\% / year; Fig. 4) and often nonsignificant (Table 1). Puccinellia generally was

226 significantly less frequent at the inland end than in the middle or seaward end of transects (Fig.

227 3; Table 1). This species increased in overall frequency between samplings at all sites, except to

228 the west of the colony at the Lumsden River, where there still was a nonsignificant increasing

229 trend (Fig. 4; Table 1). At both sites where estimation was possible, a position $\times$ year interaction 
230 indicated that the distribution of this species along the transect changed between samplings: it

231 tended to shift inland both outside the snow goose colony (at the Lumsden River) and within it

232 (at the Stitt River) (Fig. 3; Table 1). In contrast, Carex usually was more abundant at the inland

233 end of transects (Fig. 3; Table 1), reflecting the presence of freshwater seepage areas or streams.

234 Abundance was too low within the snow goose colony to meaningfully test for changes between

235 years, though it tended to occur more frequently in 2008 than 1998 (Fig. 4; Table 1); outside the

236 colony, Carex increased at the Ministik site, where an interaction also indicated a change in

237 distribution between samplings: frequency increased seaward (Fig. 3). Like Carex, Festuca also

238 was significantly more common at the inland end of transects (Fig. 3; Table 1). Changes in

239 abundance between samplings were significant at some but not all sites: outside the colony, the

240 frequency of Festuca increased slightly at the Ministik and did not change at the Lumsden,

241 though the trend was positive; inside the colony, it increased at the Stitt but not the Thompson,

242 though again there was a non-significant increasing trend (Fig. 4; Table 1).

243 Changes also occurred between samplings in the distribution and abundance of non-

244 forage species (Figs 5,6; Table 2); in most cases, these also tended to increase in overall

245 abundance (Fig. 6). In contrast, the occurrence of bare mud usually declined (Fig. 6; Table 2),

246 reflecting increases in both forage and non-forage species. Salicornia was only present in the

247 seaward and middle portions of the Lumsden transect (Fig. 5), where it greatly declined in

248 abundance between samplings (Fig. 6; Table 2); as indicated by a significant position $\times$ year

249 interaction, the few plants that survived were disproportionately concentrated at the seaward end

250 of the transect. In 1998, Spergularia occurred only at the Lumsden; in contrast, it was present at

251 all sites in 2008, though it still was to scarce to analyze statistically at the Stitt (Figs 5,6). This

252 increase was especially striking at the Thompson, where it was found in $49 \%$ of all quadrats in 
2532008 (Fig. 6), and was statistically significant at the Thompson and the Ministik (Table 2), while

254 there was a nonsignificant increasing trend at the Lumsden (Fig. 6; Table 2). As well, a

255 significant interaction indicates Spergularia moved seaward at the Lumsden, the only site where

256 it was observed in both years (Fig. 5; Table 2). Finally, Glaux occurred at all sites, where it was

257 most frequent at mid-intertidal levels (Fig. 5; Table 2). This species increased significantly at the

258 Thompson and showed an increasing trend at the Lumsden and Ministik, though not at the Stitt

259 (Fig. 6; Table 2); as well, a shift in distribution occurred at the Thompson, where it expanded

260 both seaward and landward.

261 Biomass

262 Biomass of the best remaining grazed patches of Puccinellia (Fig. 7) differed among the 263 Thompson, Stitt, and Ministik sites $\left(F_{2,17}=5.48 ; \mathrm{p}=0.01\right)$; the Lumsden transect was excluded 264 from these analyses since 2008 data were not available. Biomass was lower in the centre of the 265 colony at the Thompson than outside it at the Ministik ( $\mathrm{p}<0.05$ : Tukey HSD). Biomass did not 266 change significantly between samplings $\left(F_{1,17}=0.19 ; \mathrm{p}=0.67\right)$, and there was no site $\times$ year 267 interaction $\left(\mathrm{F}_{2,17}=0.52 ; \mathrm{p}=0.60\right)$. Mean biomass values at these sites ranged from 20-35 $\mathrm{gm}^{-2}$;

268 values at the Lumsden in 1998 (mean \pm SEM: $\left.33 \pm 2.3 \mathrm{gm}^{-2}\right)$ and $2006\left(29 \pm 3.2 \mathrm{gm}^{-2}\right)$ were 269 within this range.

270 Biomass of the best remaining Festuca (Fig. 7) did not differ among the Thompson, Stitt, 271 and Ministik sites $\left(F_{2,18}=2.10 ; \mathrm{p}=0.15\right)$; again, the Lumsden was excluded from these analyses.

272 There was an increase in biomass between years $\left(F_{1,18}=6.31 ; \mathrm{p}=0.02\right)$. These results likely 273 were influenced by an anomalously low mean and variance for the Thompson River in 1998

274 (Fig. 7); nonetheless, there was no significant site $\times$ year interaction $\left(\mathrm{F}_{2,18}=1.35 ; \mathrm{p}=0.28\right)$. The 275 low value at the Thompson may reflect sampling of an especially heavily grazed site: Festuca 
276 typically exists as a mosaic of patches (Fig. 2b) differing in grazing intensity ( $\mathrm{O}$ et al. 2006).

277 Biomass values at these sites were considerably greater than for Puccinellia, reflecting the larger 278 stature of Festuca: means ranged from 7-87 $\mathrm{gm}^{-2}$ (Fig. 7). Values at the Lumsden tended to be

279 higher than these values in both $1998\left(97 \pm 19.6 \mathrm{gm}^{-2}\right)$ and $2006\left(94 \pm 29.7 \mathrm{gm}^{-2}\right)$.

280 Discussion

281 Effects of geese on vegetation

282 Our results are consistent with a past and continuing effect of foraging by geese. Forage 283 species were scarce compared to values expected in undegraded sites (Jefferies et al. 1979; Hik 284 et al. 1992; Jefferies and Rockwell 2002), and generally were less frequent within than outside 285 the colony, where only Canada geese stage and nest. This agrees with biomass estimates which 286 even in the few relatively intact areas remaining tended to be lower at more central sites, though 287 this was significant only for Puccinellia. In contrast, non-forage species often were equally or 288 more frequent inside the colony than outside, as might be expected for species that are not 289 susceptible to goose damage and/or can tolerate the high salinity of devegetated areas. Positions 290 of species along individual transects likely often reflected gradients in physical conditions 291 (Martini and Glooschenko 1983); for instance, the tendency of Carex to occur at slightly higher 292 elevations and often closer to the freshwater (upper marsh boundary and streams) than 293 Puccinellia is expected given its lower salt tolerance, as also observed at La Pérouse Bay 294 (Jefferies et al. 1979; Jefferies and Rockwell 2002); similarly, the tendency of Festuca to occur 295 on the inland end of transects is consistent with its usual position in the supratidal zone (Jefferies 296 et al. 1979; Srivastava and Jefferies 2002). Changes in forage species between samplings provided some evidence of recovery from 2981998 conditions, but the magnitude of these changes was small. In particular, by 2008 the 299 preferred forage species Puccinellia increased both within the snow goose colony (at the 
Thompson and Stitt Rivers) and to the east (at the Ministik River), but remained far from the

301 near-continuous vegetation possible in good-quality sites (Fig. 2a), such as pre-collapse La

302 Pérouse Bay (Jefferies et al. 1979; Jefferies and Rockwell 2002). Because we measured

303 frequency rather than cover, these increases often reflected the establishment of small isolated

304 colonists (Fig. 2d) rather than continuous vegetation. This is reflected by the fact that biomass

305 values showed no significant increase, and instead remained low in both years even in the best

306 patches available $\left(\sim 30 \mathrm{gm}^{-2}\right)$. This is less than the $40-60 \mathrm{gm}^{-2}$ values typical in pre-decline

307 grazing lawns at La Pérouse Bay, but similar to post-decline values (Cargill and Jefferies 1984;

308 Jefferies and Rockwell 2002). It should be remembered that these are best-case estimates; in fact,

309 the biomass of Puccinellia in most of our $10 \mathrm{~cm}$ quadrat samples was zero, as indicated by its

310 low frequency along most transects. Similarly, though Carex subspathacea and Festuca showed

311 some tendency to increase, their cover remained far from the near-continuous swards possible in

312 undamaged or protected sites; high biomass values for Festuca reflect the fact that isolated

313 patches of good-quality vegetation may remain even in severely damaged areas ( $\mathrm{O}$ et al. 2006).

314 Some non-forage species showed large changes in abundance between samplings. In

315 particular, Salicornia nearly vanished between samplings, while Spergularia greatly increased in

316 abundance and distribution. These halophytes have similar ecological requirements and (at least

317 at the Lumsden River) occur in similar positions along the intertidal gradient; it is unclear why

318 this replacement occurred. Although it has been suggested that germination and therefore

319 population size of this annual Salicornia may be very vulnerable to year-to-year variation in

320 weather (Jefferies et al. 1983); the same principle may apply to the annual Spergularia.

321 Despite these changes, unvegetated ground remained common at all sites. Again, our

322 frequency measurements underestimate the amount of surface area actually occupied by bare

323 mud. For instance, the lower values at the Lumsden and Thompson Rivers in 2008 reflect the 
324 proliferation of Spergularia, rather than a large decline in bare space, which still was by far the

325 largest fraction of surface area.

326 Stability of goose-damaged systems

327 In springs when thaw is delayed on northern Hudson Bay-Foxe Basin nesting areas

328 (Boyd et al. 1982), interrupted migration puts unexpected foraging pressure on the vegetation of

329 staging areas in southern Hudson Bay and James Bay (Jefferies et al. 2003), because geese are in

330 a hyperphagic state at this time of pre-breeding as they accumulate reserves for egg production

331 and the final stages of migration (Wypkema and Ankney 1979). In the case of Akimiski Island,

332 the lower intertidal marshes are the communities most vulnerable to staging geese because

333 melting snow from higher elevations floods these flats, saturating the graminoid mats and

334 warming the soil, conducive to grubbing of below ground plant parts. We propose that the state

335 of the salt marsh in 1998 was likely the result of a combination of one such episode of staging

336 and foraging by a large number of snow geese in 1972 (Curtis 1973), and two succeeding

337 decades of cumulative spring grubbing and grazing damage by geese in lesser numbers.

338 Together, our results suggest that goose-damaged communities on Akimiski are very

339 slow to recover, consistent with suggestions that these sites can represent an alternative state for

340 arctic salt marsh vegetation (Abraham et al. 2005; Srivastava and Jefferies 1996; Srivastava and

341 Jefferies 2002). Despite a small, relatively stable local snow goose population and 40 elapsed

342 years since the original migratory stopover event believed to have initiated much of the current

343 devegetation, coverage by forage species at this site remains sparse compared to other less-

344 damaged locations, or to pre-degradation La Pérouse Bay (Jefferies and Rockwell 2002). This

345 suggests that a single severe impact may have been sufficient to trigger a switch of these coastal

346 wetlands into a new, persistent alternative state (van de Koppel et al. 1997; Beisner et al. 2003).

347 Although forage species did increase in frequency over our study, the rate of recovery was very 
348 low ( 1\%/year); since the colonists contributing to this increase typically were isolated or small

349 (Fig. 2d), recovery of biomass is likely to be even slower. Thus, while affected areas on

350 Akimiski technically might represent alternative transient states rather than true alternative stable

351 states (Fukami and Nakajima 2011), current evidence suggests that their persistence will be

352 prolonged.

353

Since the loss of vegetation cover, these conditions likely are being maintained in part by

354 increased surface salinity, decreased redox, and erosion of surface sediments, as also has been

355 well documented elsewhere (Srivastava and Jefferies 1996; McLaren and Jefferies 2004).

356 Experimental work at La Pérouse Bay (Handa and Jefferies 2000) and at Akimiski Island (O et

357 al. 2005, McLaren et al. unpublished) has confirmed that revegetation of such sites is difficult;

358 for instance, Festuca usually dies if transplanted into degraded sites (O et al. 2005). As well,

359 continuing foraging pressure on the remaining intertidal vegetation likely is working against

360 recovery, consistent with both models of alternative states (van de Koppel et al 1997) and results

361 of manipulative trials (Handa and Jefferies 2000). Although few in relative number compared to

362 the migrants that may have initiated the decline in 1972, nesting Akimiski Island geese are able

363 to exert significant grazing pressure on the diminished vegetation that remains (Jefferies, RL,

364 1992, unpublished report; O et al. 2006), slowing recovery; conversely, exclosure experiments at

365 La Pérouse Bay have shown recovery of intertidal vegetation can be improved by fencing

366 damaged sites (Handa et al. 2002). The slight increase we observed in forage species does

367 suggest recovery is possible even in the presence of geese, but future changes seem likely to be

368 slow, as previously predicted (Abraham et al. 2005; Jefferies et al. 2006). Clearly demonstrating

369 alternative stable states is difficult (Connell and Sousa 1983; Scheffer and Carpenter 2003;

370 Schröder et al. 2005), and Akimiski may indeed be in a process of prolonged recovery, but as at 
371 La Pérouse Bay, the combination of long-term data and field experiments indicates geese are

372 capable of triggering significant and lasting changes in northern coastal ecosystems.

\section{Acknowledgements}

374 This research was supported by NSERC (PMK); the Ontario Ministry of Natural Resources

375 (KFA), the Arctic Goose Joint Venture (Hudson Bay Project), the Mississippi Flyway Council

376 and the Central Flyway Council. Numerous members of the Akimiski Field Station provided

377 assistance, and we would especially like to thank Sarah Hagey and Rod Brook of the OMNR and

378 Jim Leafloor (Canadian Wildlife Service). This is a contribution of the Wildlife Research and

379 Development Section of the OMNR.

380 


\section{References}

382 Abraham KF, Jefferies RL (1997) High goose populations: causes, impacts and implications. In:

383 Batt BDJ (ed) Arctic ecosystems in peril: a report of the Arctic goose Habitat Working Group,

384 U.S Fish Wildl Serv Washington, DC, and Can Wildl Serv, Ottawa, Ontario, pp 7-72

385 Abraham KF, Jefferies RL, Rockwell RF (2005) Goose-induced changes in vegetation and land

386 cover between 1976 and 1997 in an arctic coastal marsh. Arctic, Antarctic, and Alpine

$387 \quad$ Research 37:269-275

388 Abraham KF, Jefferies RL, Alisauskas RT, Rockwell RF (2012) Northern wetland ecosystems

389 and their response to high densities of lesser snow geese and Ross’s geese. In: Leafloor JO,

390 Moser TJ, Batt BDJ (eds) Evaluation of special management measures for midcontinent lesser

391 snow geese and Ross’s geese. Arctic Goose Joint Venture Special Publication, U.S. Fish Wildl

392 Serv, Washington, DC and Can Wildl Serv, Ottawa, Ontario, pp 9-45

393 Abraham KF, Leafloor JO, Lumsden HG (1999) Establishment and growth of the lesser snow

394 goose nesting colony on Akimiski Island, James Bay, Northwest Territories. Can Field-Nat

$395 \quad 113: 245-250$

396 Alisauskas RT, Charlwood J, Kellett DK (2006) Vegetation correlates of nesting history and

397 density by Ross’s and lesser snow geese at Karrak Lake, Nunavut. Arctic 59:201-210.

398 Beisner BE, Haydon DT, Cuddington K (2003) Alternative stable states in ecology. Front Ecol

$399 \quad$ Environ 1:376-382

400 Blaney CS, Kotanen PM (2001) The vascular flora of Akimiski Island, Nunavut Territory. Can

$401 \quad$ Field-Nat 115:88-98

402 Boyd H, Smith GEJ, Cooch FG (1982) The lesser snow geese of the eastern Canadian Arctic:

403 their status during 1964-1979 and their management from 1982 to 1990. Can Wildl Serv

404 Occas Paper 46 pp 1-21 
405 Cargill SM, Jefferies RL (1984) The effects of grazing by lesser snow geese on the vegetation of 406 a sub-arctic salt marsh. J Appl Ecol 21:669-686

407 Connell JH, Sousa WP (1983) On the evidence needed to judge ecological stability or

$408 \quad$ persistence. Am Nat 121:789-824

409 Curtis SG (1973) The movement of geese through James Bay, Spring 1972 - A Preliminary

410 Report. Can Wildl Serv Rep, James Bay Series No. 10, pp 1-31

411 Didiuk A, Ferguson RS (2005) Land cover mapping of Queen Maud Gulf Migratory Bird

412 Sanctuary, Nunavut. Can Wildl Serv Occas Paper 111, pp 1-32

413 Fukami T, Nakajima M (2011) Community assembly: alternative stable states or alternative $414 \quad$ transient states? Ecol Lett 14:973-984

415 Gauthier G, Bety J, Giroux JF, Rochefort L (2004) Trophic interactions in a high Arctic snow 416 goose colony. Integ Comp Biol 44:119-129

417 Handa IT, Harmsen R, Jefferies RL (2002) Patterns of vegetation change and the recovery 418 potential of degraded areas in a coastal marsh system of the Hudson Bay Lowlands, J Ecol $419 \quad 90: 86-99$

420 Handa IT, Jefferies RL (2000) Assisted revegetation trials in degraded salt-marshes. J Appl Ecol $421 \quad 37: 944-958$

422 Hik DS, Sadul HA, Jefferies RL (1991) Effects of the timing of multiple grazings by geese on net 423 above-ground primary production of swards of Puccinellia phryganodes. J Ecol 79:715-730

424 Holmgren M (2002) Exotic herbivores as drivers of plant invasion and switch to ecosystem

$425 \quad$ alternative states. Biol Invasions 4:25-33

426 Jefferies RL (1988) Pattern and process in arctic coastal vegetation in response to foraging by 427 lesser snow geese. In: Gottlieb LD, Jain SK (eds) Plant evolutionary biology. Chapman and 428 Hall, London, UK. pp 341-369 
429 Jefferies RL, Jano AP, Abraham KF (2006). A biotic agent promotes large-scale catastrophic

$430 \quad$ change in coastal marshes of Hudson Bay. J Ecology 94:234-242

431 Jefferies RL, Jensen A, Abraham KF (1979) Vegetational development and the effect of geese on

$432 \quad$ vegetation at La Pérouse Bay, Manitoba. Can J Botany 57:1439-1450

433 Jefferies RL, Jensen A, Bazely D (1983) The biology of the annual Salicornia europaea agg. at

434 the limits of its range in Hudson Bay. Can J Botany 61:762-773

435 Jefferies RL, Klein DR, Shaver GR (1994) Vertebrate herbivores and northern plant

436 communities: reciprocal influences and responses. Oikos 71:193-206

437 Jefferies, RL Rockwell RF (2002) Foraging geese, vegetation loss and soil degradation in an

$438 \quad$ Arctic salt marsh. Appl Veg Science 5:7-16

439 Jefferies RL, Rockwell RF, Abraham KF (2003) The embarrassment of riches: agricultural food

440 subsidies, high goose numbers and loss of Arctic wetlands - a continuing saga. Natl Research

$441 \quad$ Council Canada, Environmental Reviews 11:193-232

442 Kerbes RH, Kotanen PM, Jefferies RL (1990) Destruction of wetland habitats by lesser snow

443 geese: a keystone species on the west coast of Hudson Bay. J Appl Ecol 27:242-258

444 Kotanen PM, Jefferies RL (1997) Long-term destruction of wetland vegetation by lesser snow

445 geese. Écoscience 4:1895-1898

446 Leafloor JO, Abraham KF, Rusch DH, Ross RK, Hill MRJ (1996) Status of the Southern James

447 Bay Population of Canada geese. In: Ratti, J (ed). Proc 7th International Waterfowl

$448 \quad$ Symposium, Memphis, Tennessee. pp 103-108

449 Leafloor JO, Hill MRJ, Rusch DH, Abraham KF, Ross RK (2000) Nesting ecology and gosling

450 survival of Canada geese on Akimiski Island, Northwest Territories. In: Dickson, KM (ed)

451 Towards conservation of the diversity of Canada geese (Branta canadensis). Can Wildl Serv

452 Occas Paper 103, pp 109-116 
453 Martini, IP, Glooschenko, WA (1984) Emergent coasts of Akimiski Island, James Bay,

454 Northwestern Territories, Canada: Geology, geomorphology, and vegetation. Sed Geol $455 \quad 37: 229-250$.

456 McLaren JR, Jefferies RL (2004) Initiation and maintenance of vegetation mosaics in an arctic $457 \quad$ salt marsh. J Ecol 92:648-660

458 O PC, Kotanen PM, Abraham KF (2005) Survival and growth of the forage grass Festuca rubra

459 in naturally and artificially devegetated sites in a sub-arctic coastal marsh. Écoscience 12:279$460 \quad 285$

461 O PC, Kotanen PM, Abraham KF (2006) Geese and grazing lawns: responses of the grass

$462 \quad$ Festuca rubra to defoliation in a subarctic coastal marsh. Can J Botany 84:1732-1739

463 Person BT, Herzog MP, Ruess RW, Sedinger JS, Anthony RM, Babcock CA (2003) Feedback

464 dynamics of grazing lawns: coupling vegetation change with animal growth. Oecologia

$465 \quad 135: 583-592$

466 Scheffer M, Carpenter SR (2003) Catastrophic regime shifts in ecosystems: linking theory to 467 observation. Trends Ecol Evol 18:648-656

468 Schröder A, Persson L, De Roos AM (2005) Direct experimental evidence for alternative stable $469 \quad$ states: a review. Oikos 110:3-19

470 Srivastava DS, Jefferies RL (1995) Mosaics of vegetation and soil salinity: a consequence of

471 goose foraging in an arctic salt marsh. Can J Bot 73:75-83

472 Srivastava DS, Jefferies RL (1996) A positive feedback: herbivory, plant growth, salinity, and the 473 desertification of an arctic salt marsh. J Ecol 84:31-42

474 Srivastava DS, Jefferies RL (2002) Intertidal plant communities of an Arctic salt marsh: the 475 influence of isostatic uplift and herbivory. Écoscience 9:112-118. 
476 Suding KN, Gross KL, Houseman GR (2004) Alternative stable states and positive feedbacks in

477 restoration ecology. Trends Ecol Evol 19:46-53

478 van de Koppel J, Rietkerk M, Weissing FJ (1997) Catastrophic vegetation shifts and soil

479 degradation in terrestrial grazing systems. Trends Ecol Evol 12:352-356

480 van der Wal R, Sjögersten S, Woodin SJ, Cooper EJ, Jónsdóttir IS, Kuijper D, Fox TAD, Huiskes

481 AD (2007) Spring feeding by pink-footed geese reduces carbon stocks and sink strength in

482 tundra ecosystems. Global Change Biol 13:539-545

483 Wypkema R, Ankney CD (1979) Nutrient reserve dynamics of lesser snow geese staging at

484 James Bay, Ontario. Can J Zool 57:213-219. 
Table 1: Generalized linear model analyses of the distribution of forage species. Shown are results of a factorial analysis (Year, Position, Position $\times$ Year). The Thompson River and Stitt River transects were located within the dense snow goose nesting area; the Lumsden River transect was near the west edge of the nesting colony; the Ministik River transect was east of the colony. Values shown are likelihood ratio $\mathrm{X}^{2}$; ns: $\mathrm{p}>0.05$; *: $\mathrm{p}<0.05$; **: $\mathrm{p}<0.01$; ***: $\mathrm{p}<0.001$; -: sample size insufficient for analysis.

\begin{tabular}{llllll}
\hline \hline Species & Factor $^{\mathrm{a}}$ & Lumsden & Thompson & Stitt & Ministik \\
\hline Puccinellia & Year & $0.900^{\mathrm{ns}}$ & $41.016^{* * *}$ & $19.952^{* * *}$ & $31.911^{* * *}$ \\
& Position & $170.182^{* * *}$ & $65.069^{* * *}$ & $68.366^{* * *}$ & $191.579 * * *$ \\
& Position $\times$ Year & $103.906^{* * *}$ & - & $23.894^{* * *}$ & - \\
Carex & Year & & & & \\
& Position & $29.334^{\mathrm{ns}}$ & - & - & $16.412^{* * *}$ \\
& Position $\times$ Year & $8.583^{\mathrm{ns}}$ & - & - & $153.012^{* * *}$ \\
& & & - & $68.925^{* * *}$ \\
& Year & $2.191^{\mathrm{ns}}$ & $2.039^{\mathrm{ns}}$ & $22.573^{* * *}$ & $6.055^{*}$ \\
& Position & $719.517^{* * *}$ & $284.263^{* * *}$ & $278.606^{* * *}$ & $634.307^{* * *}$ \\
& Position $\times$ Year & - & $13.471^{\mathrm{ns}}$ & - & - \\
\hline \hline
\end{tabular}

" ${ }^{\mathrm{a}} \mathrm{df}$ for Year = 1; df for Position, Position x Year = 14 (Lumsden), 10 (Thompson), 6 (Stitt), 8 (Ministik). 
Table 2: Generalized linear model analyses of the distribution of non-forage species. Shown are results of a factorial analysis (Year, Position, Position $\times$ Year). The Thompson River and Stitt River transects were located within the dense snow goose nesting area; the Lumsden River transect was near the west edge of the nesting colony; the Ministik River transect was east of the colony. Values shown are likelihood ratio $\mathrm{X}^{2}$; $\mathrm{n}$; ns: $\mathrm{p}>0.05$; *: $\mathrm{p}<0.05$; **: $\mathrm{p}<0.01$; ***: $\mathrm{p}<0.001$; -: sample size insufficient for analysis. "Mud" includes intertidal and supratidal exposed mud and seaweed-covered sediments.

\begin{tabular}{|c|c|c|c|c|c|}
\hline Species & Factor $^{\mathrm{a}}$ & "Lumsden & Thompson & Stitt & Ministik \\
\hline \multirow[t]{3}{*}{ Salicornia } & Year & $80.299 * * *$ & - & - & - \\
\hline & Position & $214.074 * * *$ & - & - & - \\
\hline & Position $\times$ Year & $128.012 * * *$ & - & - & - \\
\hline \multirow[t]{3}{*}{ Spergularia } & Year & $0.311^{\mathrm{ns}}$ & $973.906 * * *$ & - & $220.216 * * *$ \\
\hline & Position & $1072.455^{* * *}$ & $135.372 * * *$ & - & $257.123^{* * *}$ \\
\hline & Position $\times$ Year & $535.048 * * *$ & - & - & - \\
\hline \multirow[t]{3}{*}{ Glaux } & Year & $2.585^{\mathrm{ns}}$ & $229.107 * * *$ & $0.792^{\mathrm{ns}}$ & $0.992^{\mathrm{ns}}$ \\
\hline & Position & $235.487 * * *$ & $241.080 * * *$ & $199.816^{* * *}$ & $322.378 * * *$ \\
\hline & Position $\times$ Year & - & $167.564 * * *$ & - & - \\
\hline \multirow[t]{3}{*}{ Mud } & Year & $30.288^{* * *}$ & $1304.504^{* * *}$ & $1.243^{\mathrm{ns}}$ & $124.323^{* * *}$ \\
\hline & Position & $238.797 * * *$ & $147.504 * * *$ & $167.343 * * *$ & $433.269 * * *$ \\
\hline & Position $\times$ Year & 209.996*** & $65.053 * * *$ & $191.729 * * *$ & $61.063 * * *$ \\
\hline
\end{tabular}

${ }^{\mathrm{a}} \mathrm{df}$ for Year = 1; df for Position, Position $\times$ Year = 14 (Lumsden), 10 (Thompson), 6 (Stitt), 8 (Ministik). 


\section{List of Figure Captions}

Figure 1: Map of Akimiski Island, indicating position of snow goose nesting and brood-rearing areas, and of transect sampling sites. Locations of transects (seaward end, uncorrected magnetic compass

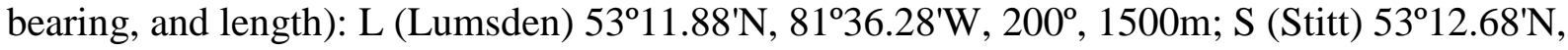

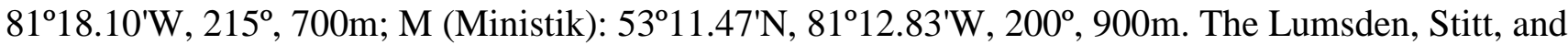
Ministik endpoints are associated with metal stakes; the Thompson (T) endpoint is back-calculated as approximately $1163 \mathrm{~m}$ at $55^{\circ}$ from an observation tower located at $53^{\circ} 11.94{ }^{\prime} \mathrm{N}, 81^{\circ} 26.29^{\prime} \mathrm{W}$.

Figure 2: a) Excellent quality Puccinellia marsh (to the right) on an island in Akimiski Strait with no evidence of goose nesting or brood-rearing (2006). Note the continuous plant cover. b) Heavily used Akimiski Island brood-rearing area, 1994. Higher areas show grubbed former Festuca rubra and vegetation there is dominated by remaining patches of Festuca rubra; lower areas contain Puccinellia phrynganodes, $\underline{\text { Carex subspathacea, }}$ and bare sediments. c) Severely devegetated intertidal flats on Akimiski Island, 2008. The tall plant is Senecio congestus. d) Typical colonizing individual of Puccinellia phryganodes, 2008; note the low cover and biomass.

Figure 3: Spatial distribution of forage species; 0m represents the seaward end of each transect. The Thompson River and Stitt River transects were located within the dense snow goose nesting area; the Lumsden River transect was near the west edge of the nesting colony; the Ministik River transect was east of the colony. Each bar represents the number of observations of that species per 100m transect segment, out of a possible total of 100 datapoints. Note the differences in horizontal scale. 
Figure 4: Overall frequency of forage species in 1998 and 2008. The Thompson River and Stitt River transects were located within the dense snow goose nesting area; the Lumsden River transect was near the west edge of the nesting colony; the Ministik River transect was east of the colony. Also shown is the number of points sampled (n); note the differences in scale.

Figure 5: Spatial distribution of non-forage species; 0m represents the seaward end of each transect. The Thompson River and Stitt River transects were located within the dense snow goose nesting area; the Lumsden River transect was near the west edge of the nesting colony; the Ministik River transect was east of the colony. Each bar represents the number of observations of that species per 100m transect segment, out of a possible total of 100 data points. Note the differences in horizontal scale.

Figure 6: Overall frequency of non-forage species in 1998 and 2008. The Thompson River and Stitt River transects were located within the dense snow goose nesting area; the Lumsden River transect was near the west edge of the nesting colony; the Ministik River transect was east of the colony. Also shown is the number of points sampled (n); note the differences in scale.

Figure 7: Biomass (mean \pm SEM) of best remaining Puccinellia and Festuca at the Lumsden (diamond), Thompson (square), Stitt (circle), and Ministik (triangle) sites. The Thompson River and Stitt River transects were located within the dense snow goose nesting area; the Lumsden River transect was near the west edge of the nesting colony; the Ministik River transect was east of the colony. 
Figure 1.

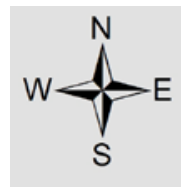

James Bay
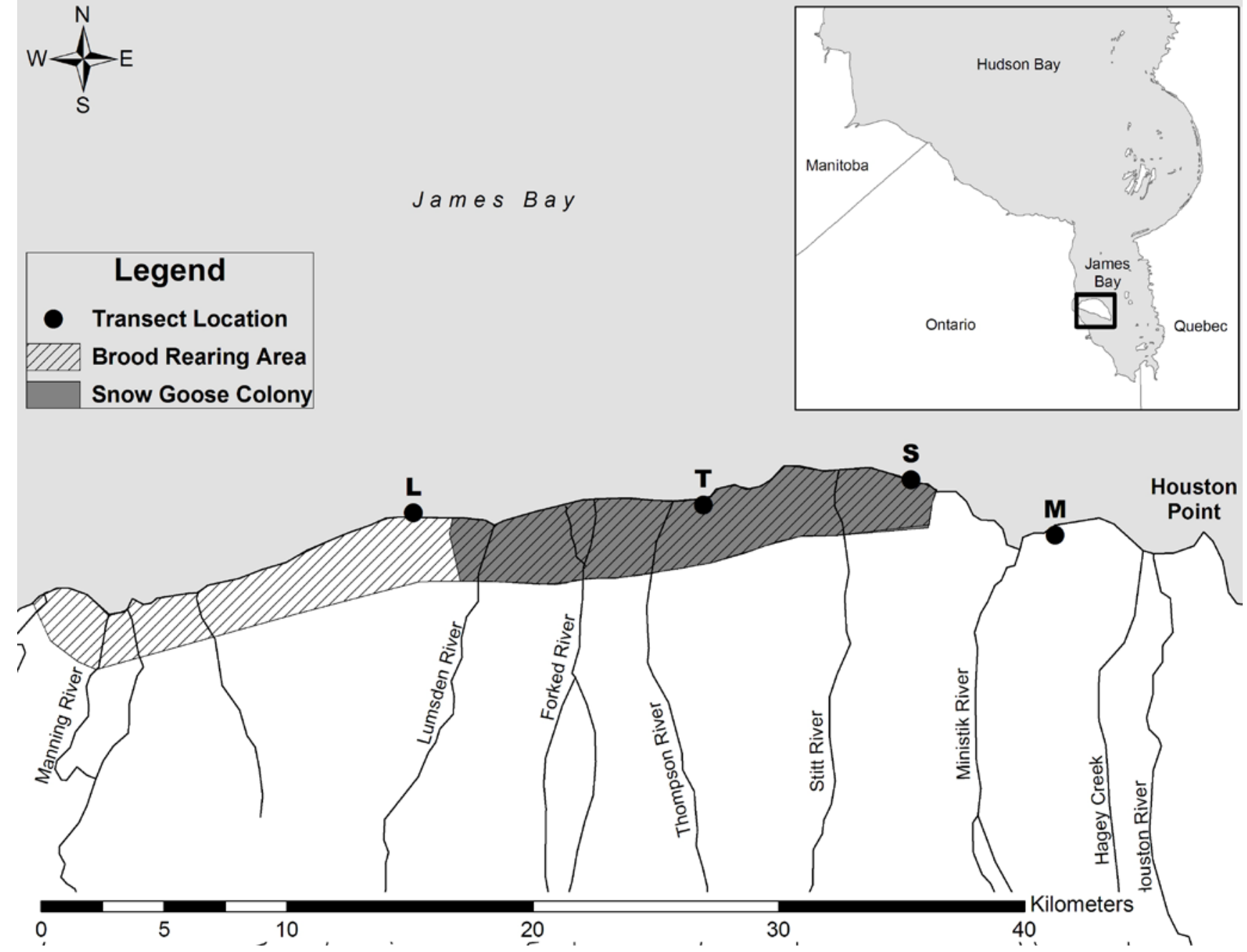
Figure 2.

a)

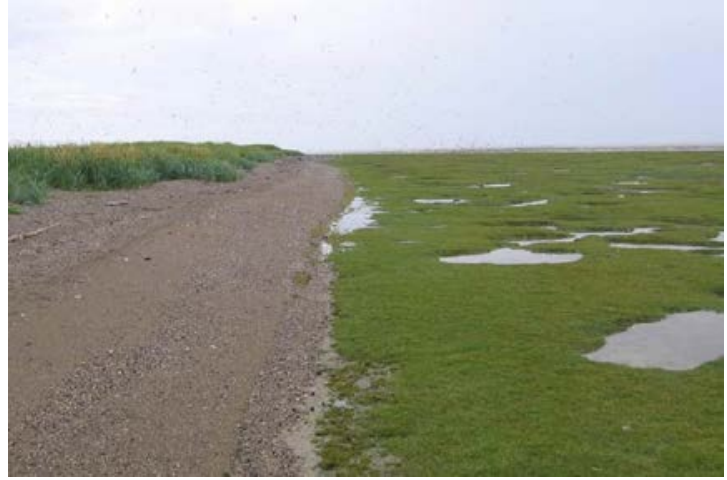

c)

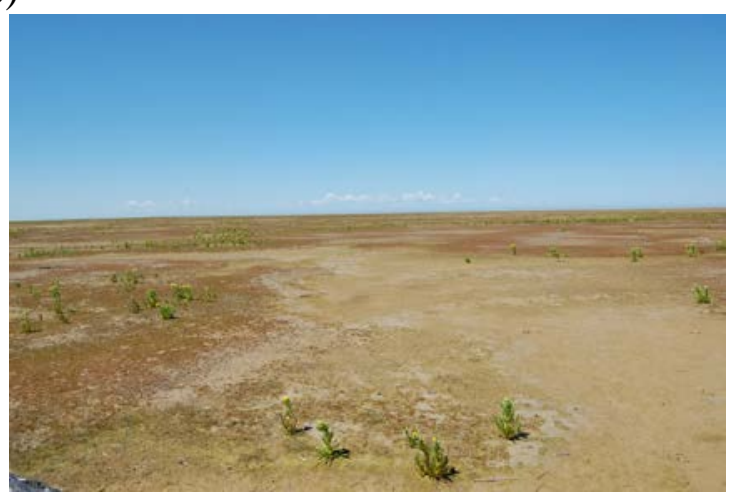

b)

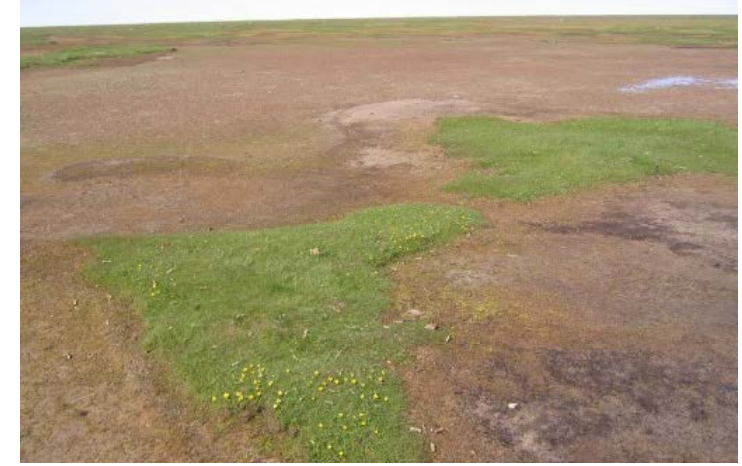

d)

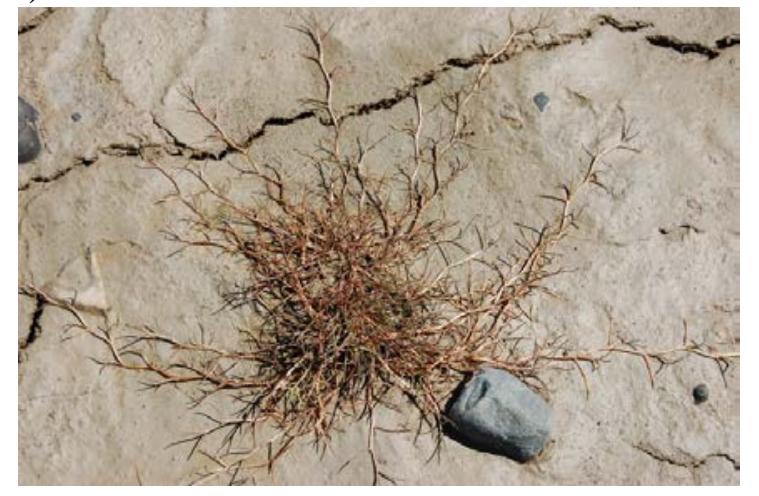


Figure 3.

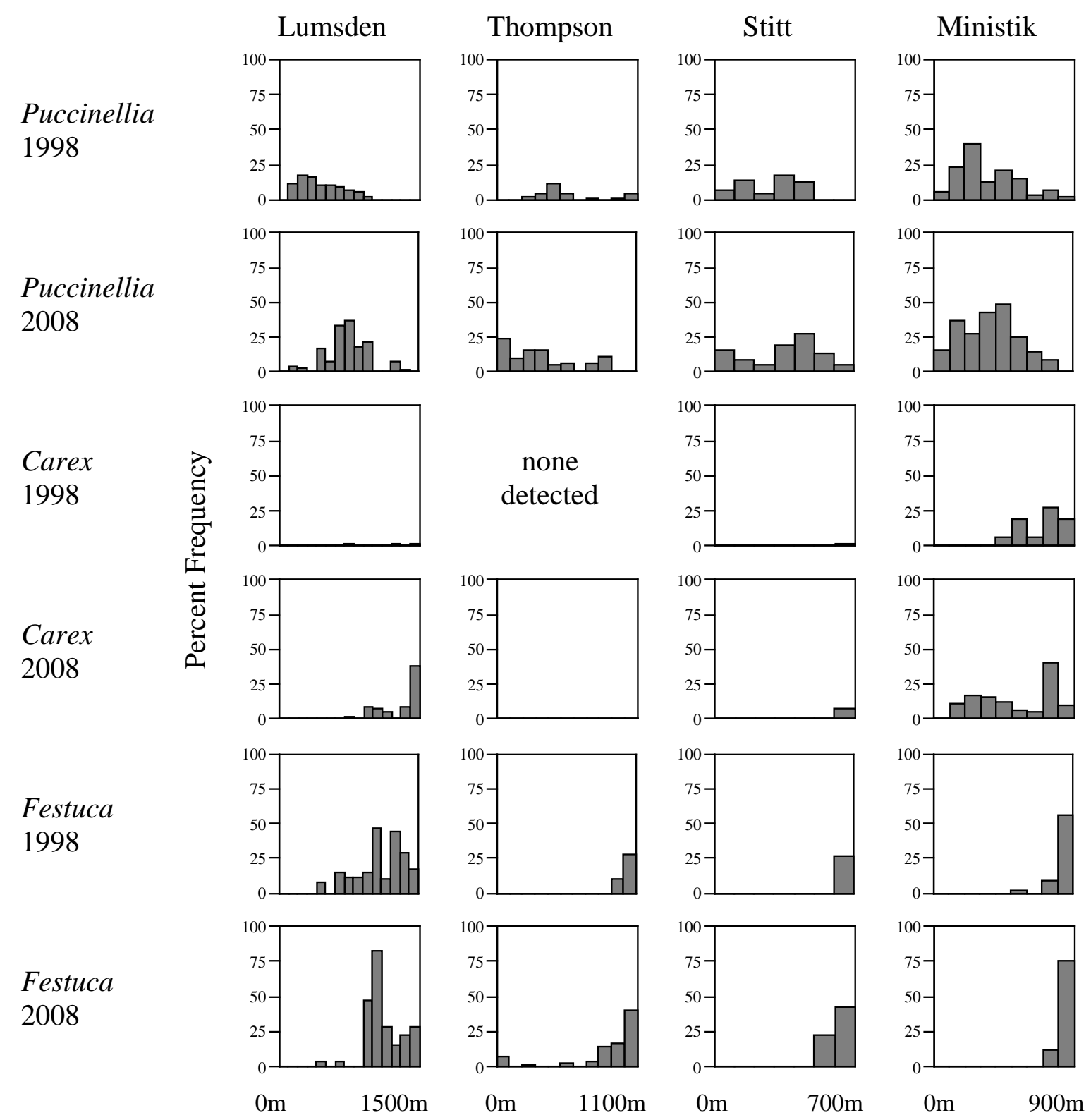


Figure 4.

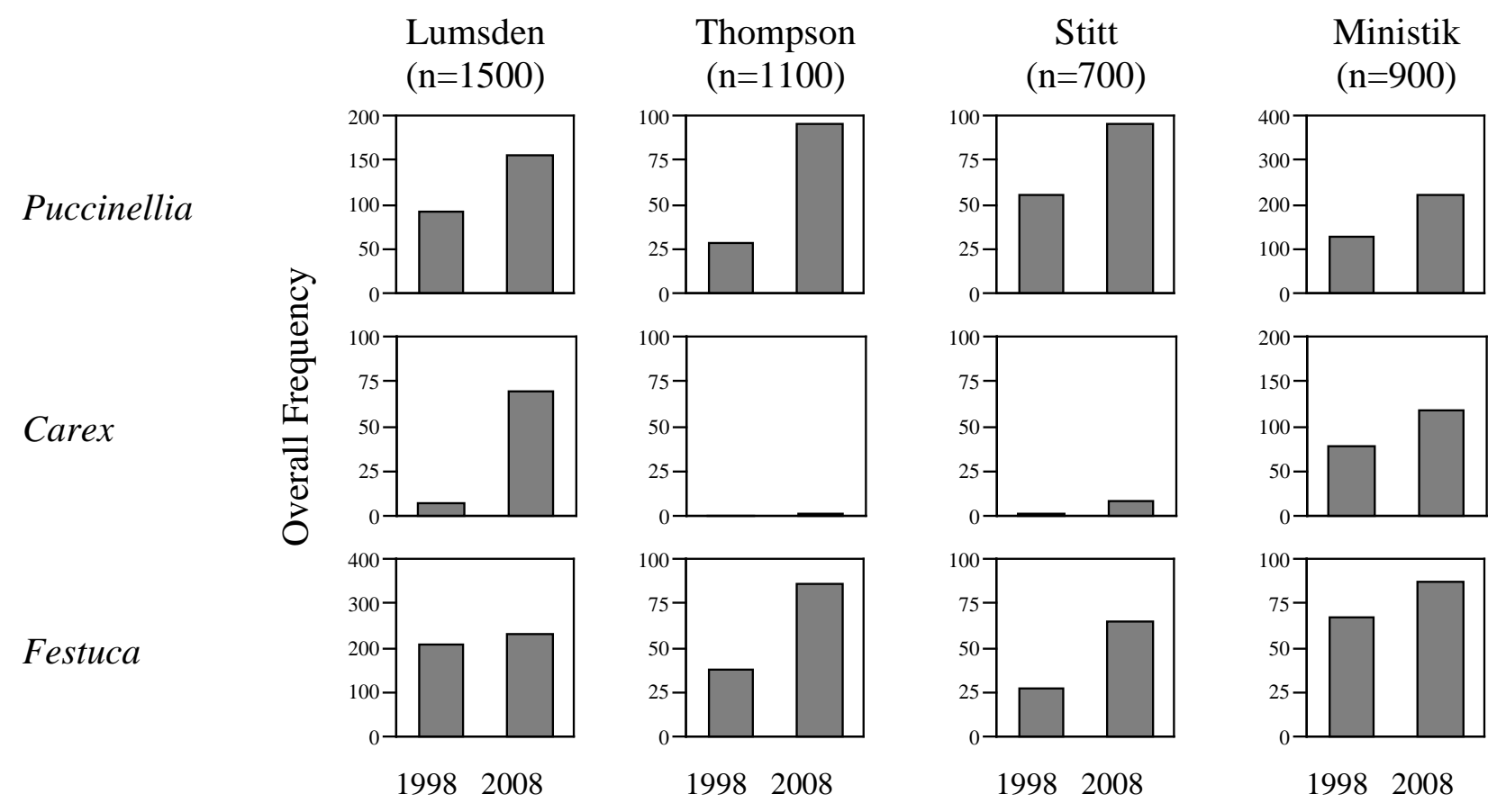


Figure 5.

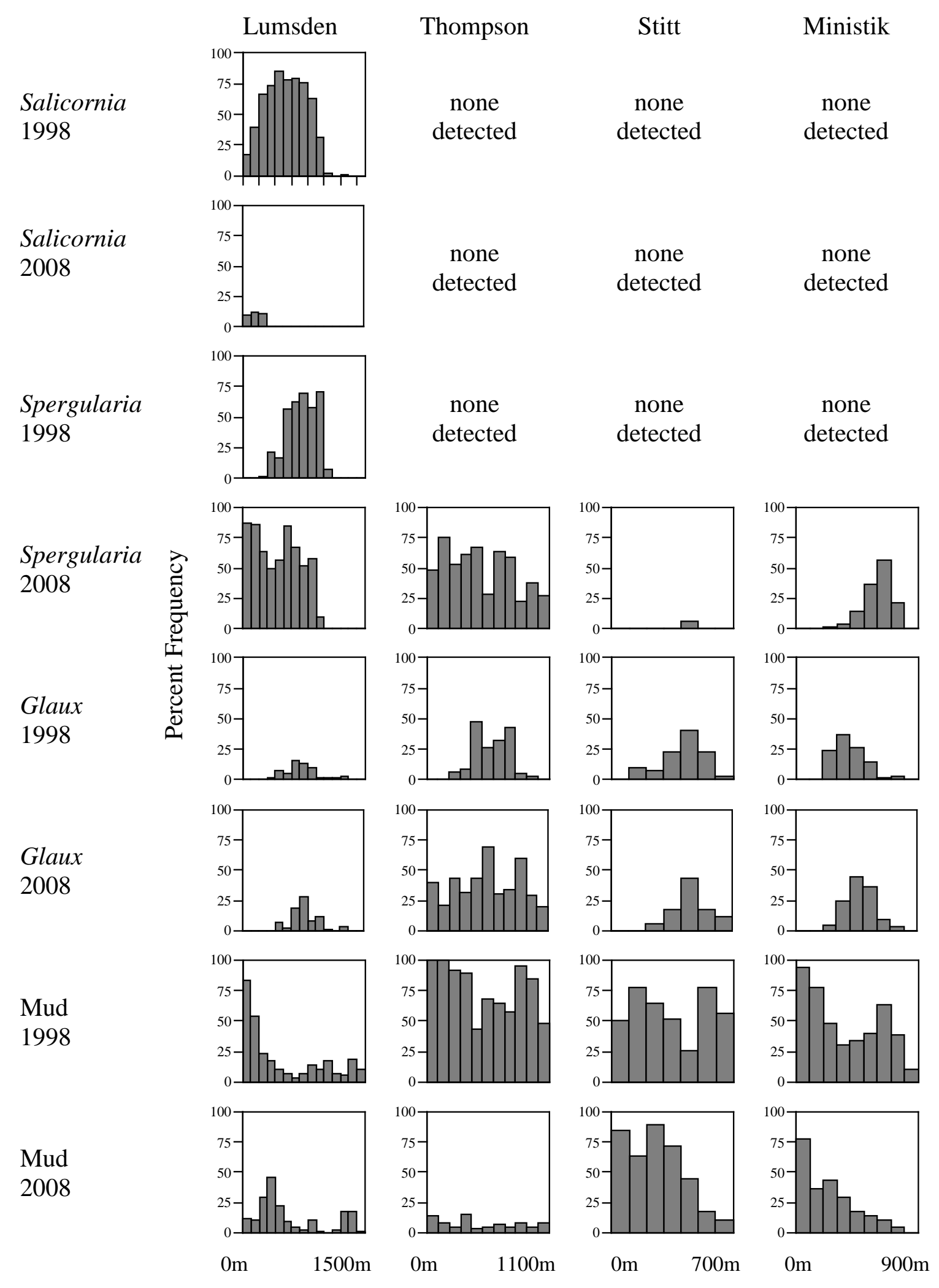


Figure 6.

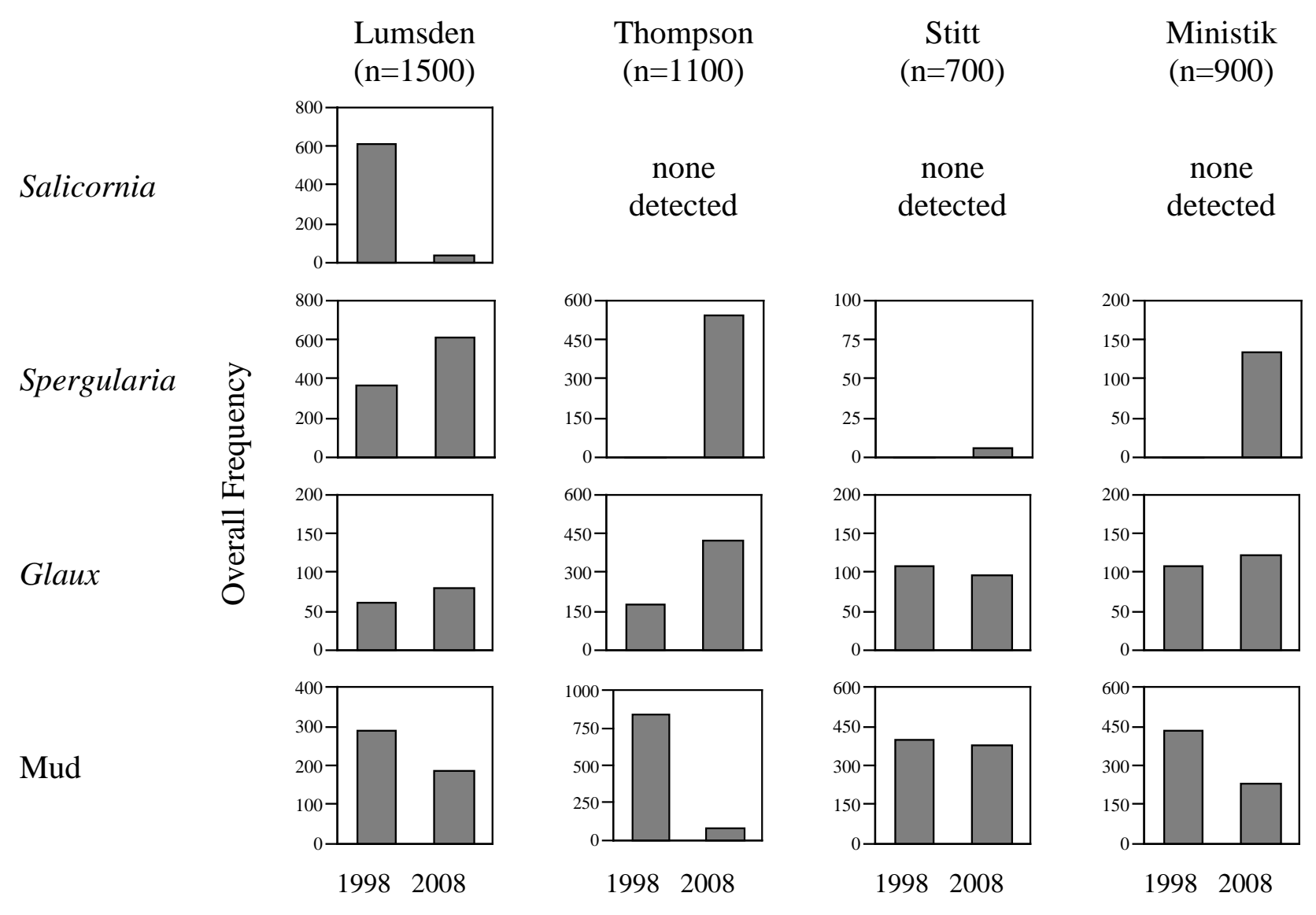


Figure 7.
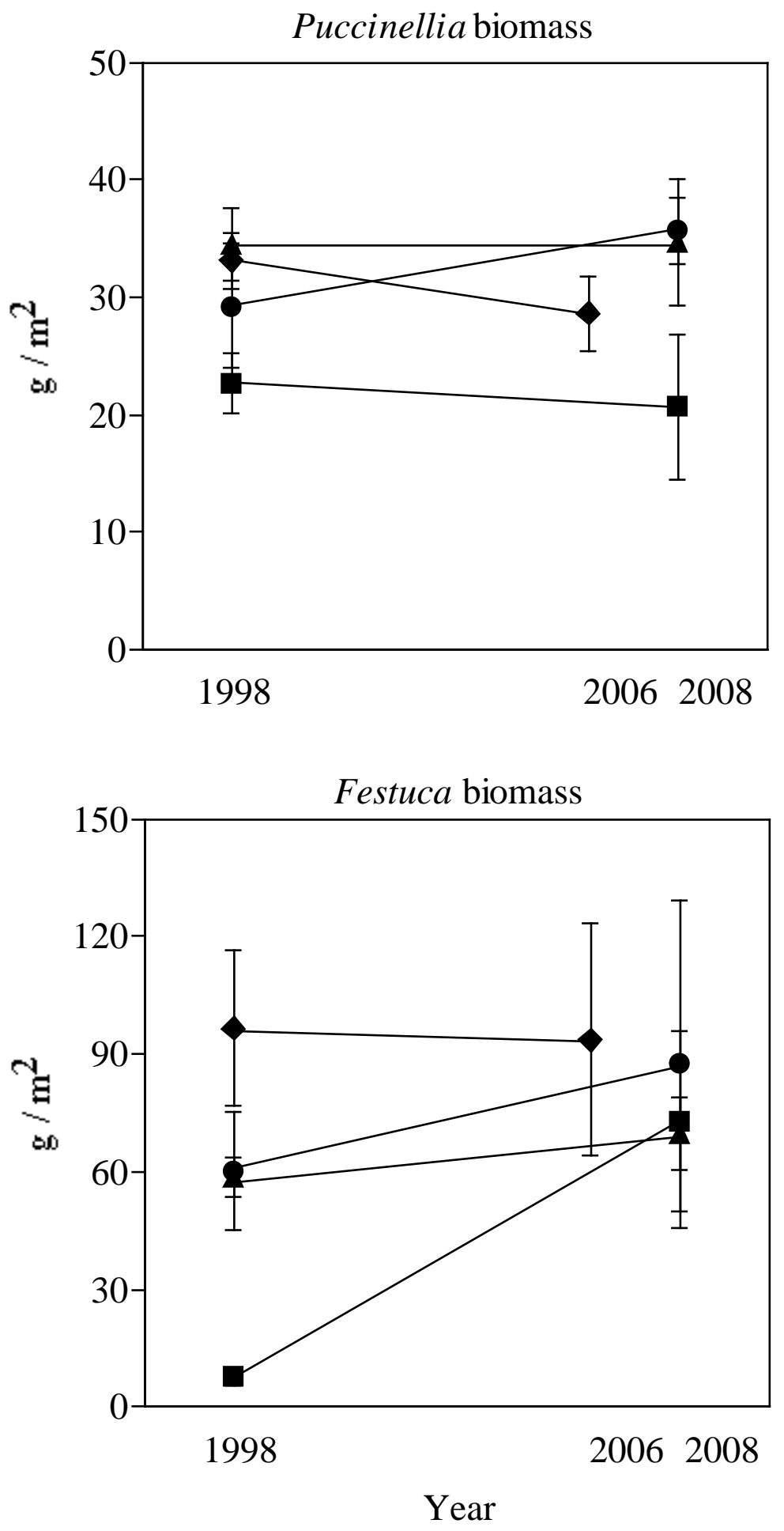